\title{
Analisis Loyalitas Konsumen Ritel Berbasis Swalayan pada Lab Bisnis
}

\author{
Oleh: \\ Ii Halilah \& Ivon Sandya Sari Putri \\ Administrasi Bisnis, Politeknik Negeri Bandung \\ Abstract
}

\begin{abstract}
The "Lab Bisnis", which is a Business Administration Dept's laboratorium, is a kind of convenient store. The daily transactions which influences the profit of the store are very low compared with other competitor. This condition might happens because of the low level of customer loyalty. This study found that the customer loyalty factor of Lab Bisnis are high in repeat buying \& referrals factors. However, as for the retention behaviour, it should be increased by the management. The study can being a modul for arrange the loyalty strategy program in next future.
\end{abstract}

Keywords: Customer loyalty and retail business

\section{PENDAHULUAN}

Sebagai salah satu wadah untuk mahasiswa dapat mempelajari secara riil praktik retail berbasis swalayan, Laboratorium Bisnis telah menjadi sebuah bisnis ritel berbasis swalayan yang nyata yang dalam pelaksanaannya dikelola secara profesional. Hal ini salah satunya ditunjukkan dengan nilai laporan keuangan tahunan yang meningkat setiap tahunnya, dengan Keuntungan/Laba bersih tahun 2015 yang lalu adalah sebesar Rp 22.753.798,- (lihat lampiran) dengan rata-rata jumlah transaksi mencapai 250 - 350 transaksi per hari. Akan tetapi, nilai keuntungan dan transaksi yang diperoleh tersebut masih dapat dikategorikan rendah bila dibandingkan dengan bisnis serupa khususnya pada lingkungan Politeknik Negeri Bandung.

Beberapa faktor dapat melatarbelakangi situasi diatas, salah satunya diduga karena rendahnya tingkat loyalitas konsumen. Dalam persaingan bisnis ritel saat ini, faktor lingkungan toko, harga, produk yang ditawarkan, hingga teknologi operasional menjadi faktor yang wajib dipertimbangkan oleh para pelaku bisnis ritel berbasis swalayan. Berdasarkan observasi penulis, dalam hal lingkungan toko, Lab Bisnis sudah mempunyai keunggulan tersendiri dari segi lokasi yang strategis. Dalam hal harga dan produk, Lab Bisnis telah menawarkan berbagai macam makanan, minuman, kebutuhan sehari-hari hingga perlengkapan ATK dengan harga yang murah dan bersaing. Lab Bisnis secara operasional juga sudah didukung oleh teknologi aplikasi penjualan dan pembelian yang memudahkan dalam mengawasi persediaan barang dan memudahkan dalam pencatatan penjualan.

Dengan penjelasan faktor diatas, diperlukan adanya studi untuk mengetahui lebih dalam faktor yang menyebabkan rendahnya nilai keuntungan dan transaksi di Lab Bisnis, yaitu berkaitan dengan loyalitas konsumen, dimana loyalitas konsumen berperan besar, dengan dicirikan salah satunya adalah banyaknya konsumen yang datang dan bertransaksi. Konsumen yang loyal dideskripsikan sebagai konsumen yang mempunyai sikap yang kuat terhadap sebuah produk yang membuat tingginya level pembelian kembali (Baloglu, 2002), dalam hal ini adalah terlihat dari banyaknya transaksi.

Liputan6.com mencatat, gerai ritel di Indonesia terus mengalami pertumbuhan yang positif dalam 10 tahun terakhir, baik ritel swalayan maupun ritel non swalayan yang mencapai lebih dari 765 ribu gerai. Lebih lanjut, Direktur Jenderal Perdagangan, Srie Agustina menyatakan bahwa pertumbuhan tersebut di dominasi oleh ritel tradisional sebanyak 750 ribu gerai atau tumbuh sebesar $42 \%$ dan ritel modern dalam format mini market dengan pertumbuhan sebanyak 16 ribu gerai atau tumbuh sebesar $400 \%$. Kebutuhan konsumen akan 
keberadaan perusahaan ritel terus meningkat. Peningkatan usaha ritel ini membuat persaingan yang terjadi menjadi semakin tinggi sebagai akibat semakin banyaknya ritel-ritel lokal dan asing yang muncul saat ini. Kondisi seperti ini yang mengakibatkan semakin tingginya tingkat persaingan, sehingga menuntut para pemasar perusahaan untuk lebih inovatif dalam menciptakan strategi pemasaran tanpa mengesampingkan keinginan konsumen serta kepentingan perusahaan.

Dalam perjalanannya, sebuah bisnis perlu untuk meningkatkan jumlah pelanggan disertai dengan meningkatkan kepuasan para pelanggan serta loyalitas pelanggan. Hal ini perlu dilakukan karena berdasarkan Griffin (2002), terdapat lima alasan untuk membuat seorang pelanggan loyal yaitu:

1. Penjualan akan meningkat karena pelanggan akan selalu membeli lebih.

2. Ketika konsumen membeli produk dari bisnis tersebut bukan dari kompetitor, maka itu menguatkan posisi bisnis tersebut di pasar.

3. Biaya pemasaran menurun ketika perusahaan tidak mempunyai dana untuk menarik konsumen.

4. Perusahaan akan terpisahkan dari kompetisi harga karena konsumen yang loyal tidak begitu tertarik dengan harga diskon yang hanya sepersekian dollar.

5. Seorang konsumen yang loyal dengan senang hati mencoba contoh dari lini produk yang lain dalam bisnis sehingga dapat mencapai pasar yang lebih luas.

Kegiatan meningkatkan kepuasan konsumen juga harus disertai dengan membuat konsumen loyal, karena ketika konsumen merasa puas belum berarti mereka juga loyal terhadap perusahaan.Walaupun konsumen sudah sangat puas terhadap kualitas produk/jasa, pada kenyataannya masih banyak juga yang berpindah ke merek lain. Hal ini disebabkan karena diferensiasi diantara produk-produk yang ada tidak terlalu signifikan. Alasan lain mengapa konsumen yang puas tidak selalu loyal, adalah karena didorong oleh tawaran yang menarik dari kompetitor yang sulit ditolak oleh konsumen. Selain itu juga karena pada dasarnya manusia selalu ingin mencoba sesuatu yang baru, untuk itu diperlukan strategi yang tepat untuk mempertahankan pelanggan. Pelanggan yang loyal secara aktif akan mempromosikan perusahaan dan memberikan rekomondasi kepada kerabat dan sahabat mereka, menjadikan perusahaan sebagai pilihan utama dan tidak mudah untuk berpindah ke kompetitor lain, serta menambah frekuensi pembelian pada perusahaan.

Berdasarkan uraian di atas, terlebih dahulu diperlukan pengukuran sejauh mana loyalitas konsumen pada Lab Bisnis untuk selanjutnya digali faktor apa saja yang mempengaruhi loyalitas konsumen Lab Bisnis, maka peneliti tertarik untuk melakukan penelitian tentang "Analisis Loyalitas Konsumen Bisnis Ritel Berbasis Swalayan Sebagai Lab. Bisnis".

\section{TINJAUAN PUSTAKA}

Oliver (1997) berpendapat bahwa "customer loyalty is deefly held commitment to rebuy or repatronize a preferred product or service consistenly in the future, despite situasional influences and marketing effort having the potential to cause switching behavior." Di samping itu, menurut Griffin (2002), "Loyalty is defined as non random purchase expressed over time by some decision making unit". Dick \& Basu (1994) mendefiniskan loyalitas sebagai sebuah kombinasi dari hubungan sikap yang kuat dan tingkat pengulangan pembelian dalam bisnis yang tinggi. Berdasarkan definisi tersebut dapat dijelaskan bahwa loyalitas lebih mengacu pada wujud perilaku dari unit-unit pengambil keputusan untuk melakukan pembelian secara terus menerus terhadap barang atau jasa suatu perusahaan.

Penelitian terakhir menyimpulkan bahwa loyalitas konsumen merupakan sebuah hal yang rumit dan mengandung komponen sikap dan perilaku (Baloglu, 2002). Komponen sikap dari loyalitas lebih focus kepada tingkat komitmen konsumen dan intensi terhadap sebuah produk. Hal tersebut dicirikan dengan konsumen yang sering menceritakan sisi positif dari 
sebuah produk/ merek dan seberapa bagus sebuah produk tersebut. Sedangkan loyalitas perilaku berlangsung ketika intensi tersebut diubah menjadi aksi. Seperti yang dijelaskan oleh Kumar dan Shah (2004), program loyalitas paling banyak adalah pada loyalitas perilaku yang artinya semakin sering konsumen berinteraksi dengan perusahaan, semakin banyak reward yang diterima oleh konsumen. Loyalitas yang sebenarnya bersumber dari perilaku pembelian yang tertanam dalam sikap positif terhadap sebuah produk atau brand (Day, 1969).Karakteristik dari konsumen yang loyal menurut Griffin (2002), antara lain adalah:

a. Melakukan pembelian ulang secara teratur (repeat purchase).

b. Membeli diluar lini produk atau jasa.

c. Mengajak orang lain (referrals).

d. Menunjukan kekebalan dari tarikan persaingan (tidak mudah terpengaruh oleh tarikan persaingan produk sejenis atau retention).

Menurut Griffin (2002), meningkatkan loyalitas pelanggan dapat menghemat biaya yang dikeluarkan perusahaan pada enam area, yaitu:

a. Mengurangi biaya pemasaran (karena biaya untuk menarik konsumen barulebih mahal),

b. Mengurangi biaya transaksi, biaya negosiasi kontrak, pemrosesan pesanan,dan lain-lain,

c. Mengurangi biaya turn over konsumen (karena pergantian konsumen yanglebih sedikit),

d. Meningkatkan penjualan silang, yang akan memperbesar pangsa pasar perusahaan,

e. Word of Mouth yang lebih positif, dengan asumsi bahwa konsumen yangloyal juga berarti mereka yang merasa puas, dan

f. Mengurangi biaya kegagalan (misalnya biaya penggantian).

\section{METODOLOGI PENELITIAN}

Penelitian ini dilakukan terhadap para konsumen bisnis ritel Lab Bisnis yang pernah berbelanja di toko Lab Bisnis, termasuk didalamnya adalah mahasiswa dan dosen. Penelitian menggunakan metode deskriptif dan verifikatif, hal ini dilakukan dalam bentuk analisis data primer dari hasil penyebaran kuesioner. Sebelum dilakukan pengambilan data, peneliti terlebih dahulu melakukan pilot testing untuk mengetahui sejauh mana responden memahami kuesioner dari segi bahasa dan perintah. Setelah data terkumpul, peneliti melakukan pengolahan dan analisa data sebelum akhirnya data tersebut disusun untuk tahap pelaporan analisa data.

Sampel dari penelitian ini adalah 150 konsumen Lab Bisnis Ritel Polban. Yang dimaksud dengan konsumen adalah seseorang yang pernahmelakukan transaksi dari berbelanja di Lab Bisnis Ritel Polban. Hal ini dilakukan agar data yang diperoleh dapat benarbenar dipercaya dan akurat serta sesuai dengan sifat dari jasa yang baru dapat dirasakan dan dinilai oleh konsumen setelah konsumen tersebut selesai menerima layanan atau jasa tersebut.Teknik sampling yang akan dilakukan oleh peneliti adalah teknik non probability sampling. Teknik ini digunakan karena jumlah populasi konsumen yang mengunjungi Lab Bisnis Ritel cukup besar dan karena keterbatasan waktu, biaya dan tenaga.Kriteria sampel dalam penelitan ini adalah mereka yang berusia 15 tahun sampai 65 tahun yang pernah berbelanja atau mengunjungi lab bisnis Berbasis Ritel.

\section{Instrumen Penelitian}

Instrumen yang digunakan untuk penelitian ini adalah kuesioner. Kuesioner yang digunakan terdiri atas dua bagian. Bagian pertama berisikan 6 pertanyaan untuk mengeksplor tentang sifat loyalitas konsumen toko lab bisnis.Bagian kedua berisikan tentang pertanyaan mengenai profil responden, seperti jenis kelamin, umur, lamanya di Polban, dan pengeluaran perbulan.

Penilaian kuesioner ini diukur berdasarkan sekala likert 1 sampai 5 yang memungkinkan responden untuk memilih jawaban dan dari setiap pernyataan sesuai dengan pengalaman dan penilaian konsumen atas produk \& layanan yang telah diterimanya di Lab 
Bisnis Ritel.Bobot penilaian skala likert untuk loyalitas konsumenberisikan lima skala yaitu : nilai "1" berarti "Sangat Tidak Setuju (STS)", "2" berarti "Tidak Setuju (TS)", "3" berarti "Netral (N)", "4" berarti "Setuju (S)", dan "5" berarti "Sangat Setuju (SS)".

\section{Metode Analisis Data}

Data yang diperoleh dianalisis menggunakan program IBM SPSS Statistics 21 (Statistical Product of Service Solution) Teknik analisa yang digunakan adalah analisa frekuensi dan faktor yang dihitung berdasarkan angka-angka yang diperoleh dari hasil pengolahan data penelitian.

\section{HASIL PENELITIAN}

\section{Data Demografi}

Dari rencana kuesioner yang disebarkan sebesar 150 buah, kami mendapatkan tambahan jumlah responden sebanyak 160 responden, hal ini terjadi pada penyebaran kuesioner via on-line kuesioner. Dari 160 kuesioner yang terkumpul, berikut Tabel 1 menampilkan data demographic dari responden penelitian ini.

Tabel 1 . Demographic Data Responden

\section{Jenis Kelamin}

Perempuan

Laki-laki

Usia

$<20$ tahun

20-25 tahun

25-30 tahun

35-40 tahun

$>40$ tahun

\section{Lama di Polban}

$<1$ tahun

5-10 tahun

$>10$ tahun

\section{Pengeluaran per Bulan}

\begin{tabular}{rr}
$<\operatorname{Rp} 1.000 .000$ & 94 \\
$\operatorname{Rp} 1.000 .001-\operatorname{Rp} 3.000 .000$ & 64 \\
$\operatorname{Rp} 3.000 .001-\operatorname{Rp} 4.000 .000$ & - \\
$>\operatorname{Rp} 4.000 .000$ & 1 \\
\hline
\end{tabular}




\section{Analisis Deskriptif}

Gambar 1 menunjukkan tingkat loyalitas konsumen Lab Bisnis, dimana konsumen akan melanjutankan untuk berbelanja produk kebutuhan konsumen di Lab Bisnis. Dari Gambar 1, terlihat bahwa dari total seluruh responden, $47 \%$ setuju dan $25 \%$ sangat setuju untuk melanjutkan berbelanja produk kebutuhan mereka di Lab Bisnis. Akan tetapi, terdapat $1 \%$ dari jumlah responden yang tidak akan melanjutkan berbelanja produk di Lab Bisnis AN, dan sisanya $27 \%$ mempunyai aksi netral untuk akan melanjutkan berbelanja produk di Lab Bisnis. Hal ini menarik untuk dicermati lebih lanjut guna mendapatkan alasan mengapa jumlah responden tersebut ragu untuk melanjutkan berbelanja produk kebutuhan mereka di Lab Bisnis.

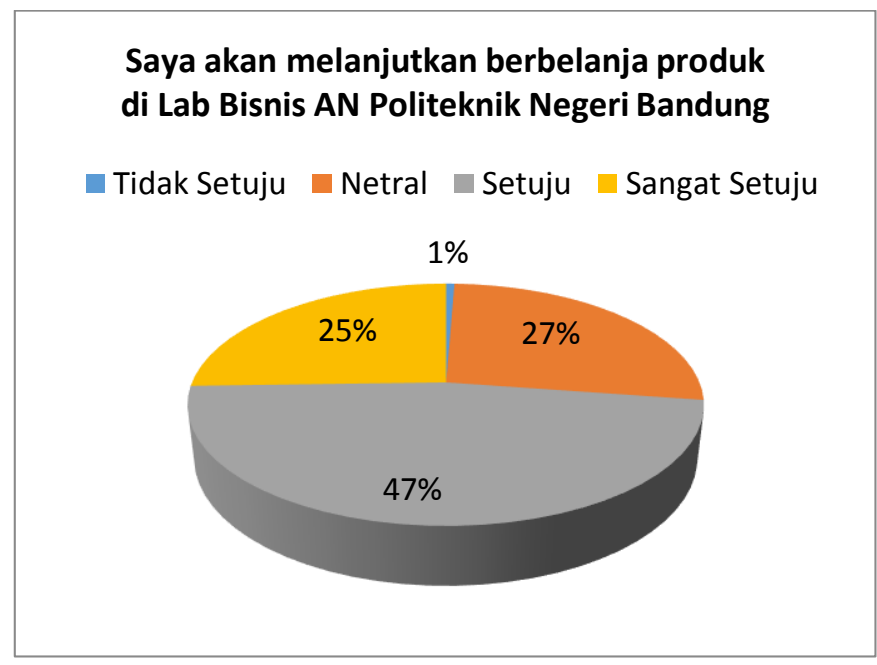

\section{Gambar 1 . Deskripsi Question 1}

Selanjutnya, diperlihatkan pada Gambar 2, bahwa dari total responden 38\% dan 21\% menyatakan setuju dan sangat setuju bahwa pelayanan Lab Bisnis sudah baik sehingga mereka akan tetap berbelanja produk yang sama juga berbeda di Lab Bisnis. Namun, masih terdapat 35\% dari responden yang ragu untuk berbelanja produk yang sama dan berbeda di Lab Bisnis. Lebih lanjut, terdapat $6 \%$ dari jumlah total responden yang menyatakan tidak setuju dengan pelayanan Lab Bisnis dan tidak akan tetap berbelanja produk yang sama maupun berbeda di Lab Bisnis. Hal ini dapat diartikan bahwa mereka akan berpindah tempat berbelanja dikarenakan kualitas pelayanan Lab Bisnis yang mereka rasakan kurang. Angka ini perlu ditelaah lebih lanjut dan digali latar belakang alasan dari nilai ini guna memperbaiki kualitas pelayanan Lab Bisnis AN.

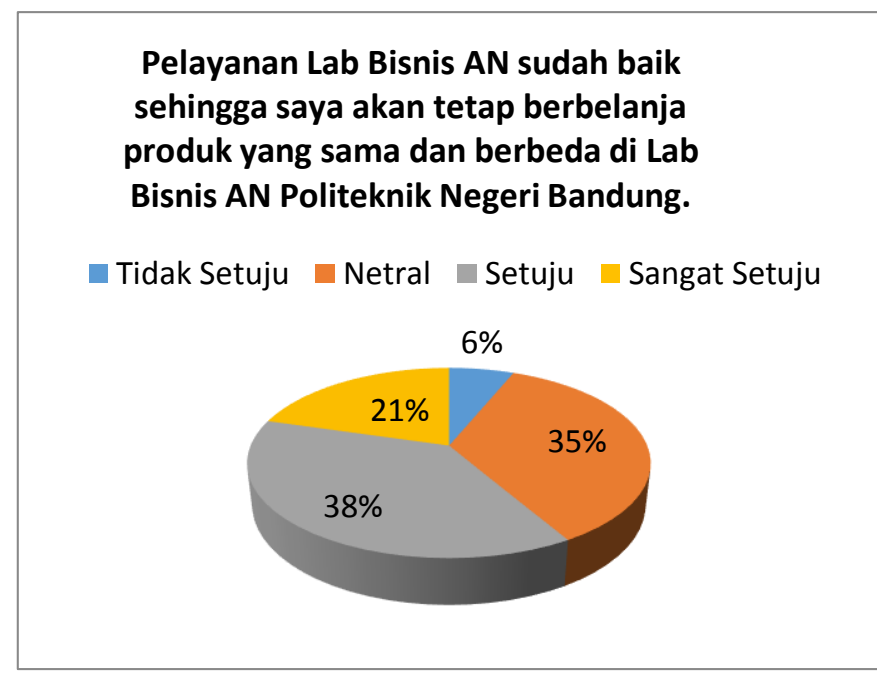

Gambar 2 . Deskripsi Question 2 
Pada Gambar 3, hasil análisis deskriptif memperlihatkan bahwa hanya 1\% dari total responden yang menyatakan bahwa mereka sangat setuju dan $14 \%$ setuju tidak tertarik dengan tempat berbelanja lain selain Lab Bisnis. Adapun $40 \%$ dari total responden ragu akan ketertarikannya dengan tempat berbelanja lainnya. Lebih lanjut, dipastikan 33\% dari total responden yang berasal dari pengungjung Lab Bisnis menyatakan bahwa mereka tertarik dengan tempat berbelanja lain selain Lab Bisnis. Hal tersebut menandakan bahwa Lab Bisnis Ritel tidak cukup mempunyai keunikan yang dapat menahan konsumennya untuk hanya berbelanja di Lab Bisnis.

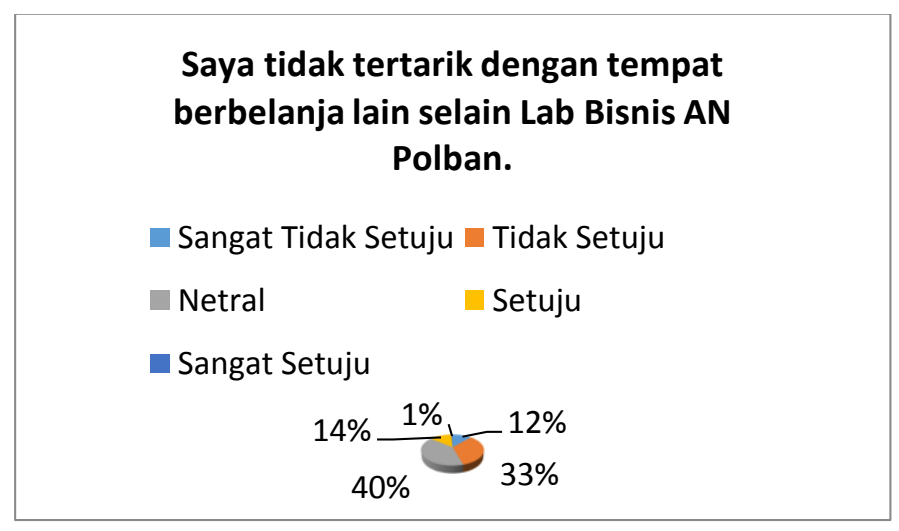

Gambar 3 . Deskripsi Question 3

Pada penjelasan yang berkaitan dengan kualitas produk yang ditawarkan sehingga membuat konsumen akan selalu berbelanja di Lab Bisnis, Gambar 4 menunjukkan bahwa hanya $29 \%$ dari total responden yang setuju dengan perihal tersebut dan $7 \%$ yang sangat setuju. Dan lebih lanjut terdapat $11 \%$ dari total responden yang tidak setuju akan produk yang ditawarkan Lab Bisnis berkualitas, sehingga mereka tidak akan selalu berbelanja di Lab Bisnis. Sisanya sebanyak 52\% menyatakan netral akan pernyataan tersebut. Nilai yang cukup besar ini perlu mendapatkan perhatian lebih lanjut karena berkaitan dengan kualitas produk pada Lab Bisnis yang mempengaruhi keinginan untuk konsumen untuk selalu berbelanja di Lab Bisnis.

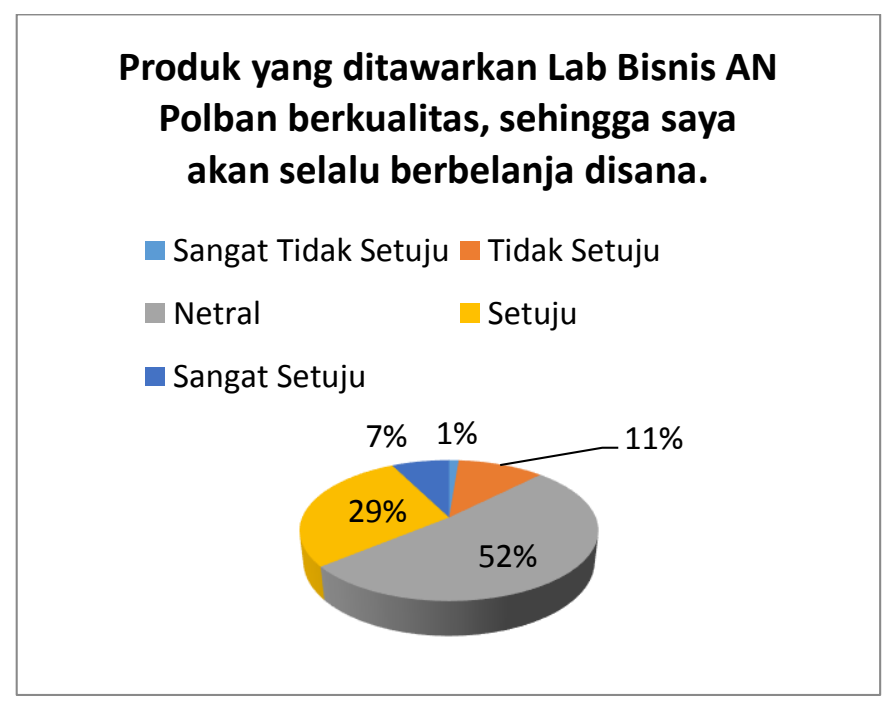

Gambar 4 . Deskripsi Question 4

Pada Gambar 5 selanjutnya menunjukkan bahwa $43 \%$ dari total responden menyatakan setuju jika mereka akan merekomendasikan produk Lab Bisnis kepada orang lain, dan $11 \%$ menyatakan sangat setuju dengan hal tersebut. Hal ini dapat menunjukkan bahwa Word of mouth dapat dikembangkan sebagai alat pemasaran untuk Lab Bisnis. Namun, masih terdapat $35 \%$ dari total responden yang ragu untuk bisa merekomendasikan produk Lab Bisnis 
kepada orang lain. Nilai yang masih terbilang tinggi untuk bisa menghambat strategi Word of mouth untuk Lab Bisnis sehingga perlu diteliti lebih lanjut tentang angka ini.

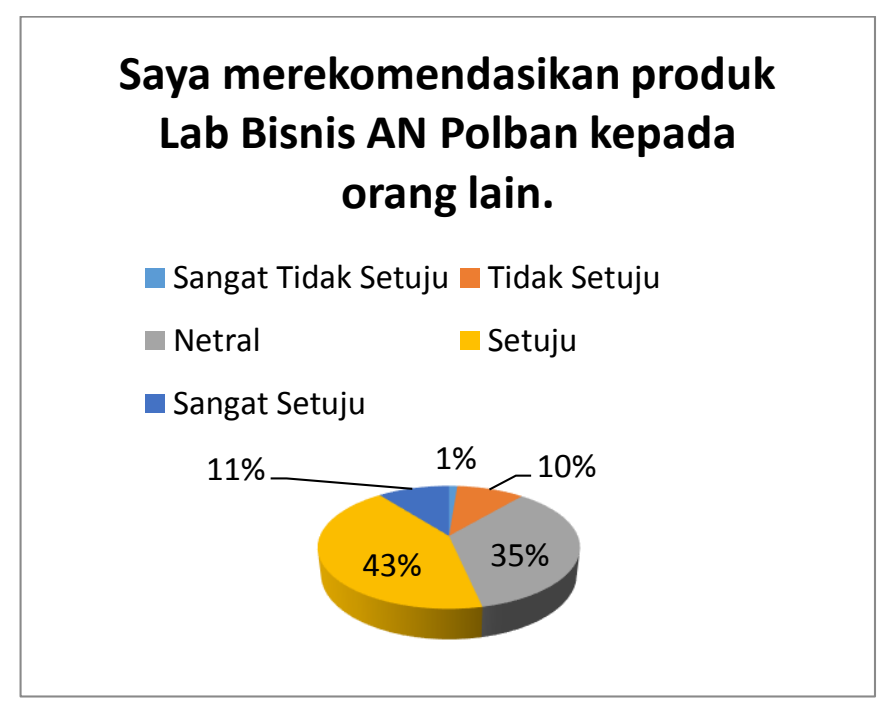

\section{Gambar 5 . Deskripsi Question 5}

Hasil respon dari pernyataan yang berkaitan dengan penyebaran isu negative tentang Lab Bisnis, dijelaskan pada Gambar 6 yang menunjukkan bahwa 40\% dari total responden setuju dan 32\% sangat setuju bahwa mereka tidak pernah menyebarkan isu negative tentang Lab Bisnis. Hal ini menunjukkan kondisi yang baik bagi Lab Bis untuk dapat merencanakan strategi pemasaran seperti contohnya Word of mouth.

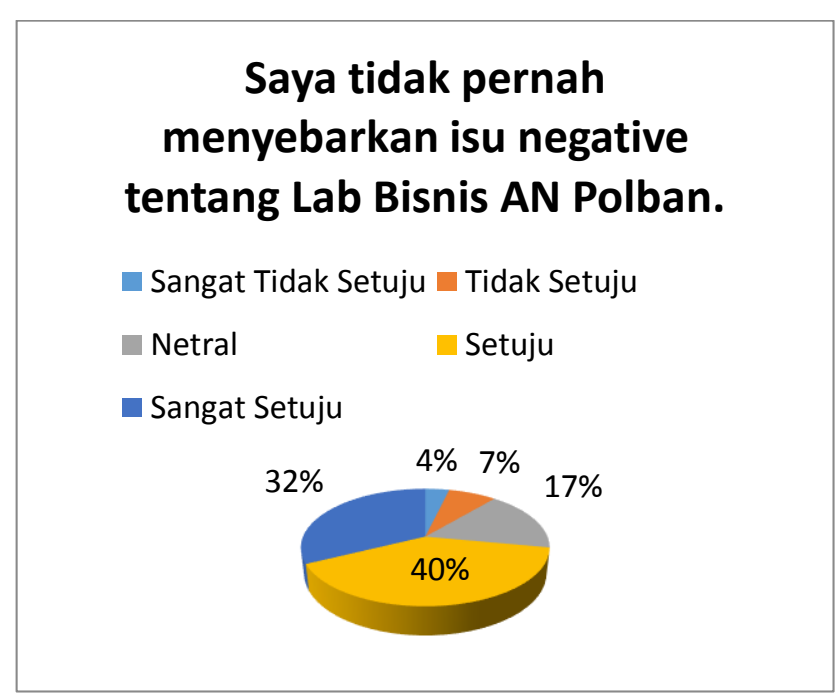

Gambar 6 . Deskripsi Question 6

\section{Analisis Faktor}

Analisis faktor digunakan untuk mengelompokkan respon dari pernyataan-pernyataan kuesioner yang telah dijawab oleh para responden berkaitan dengan loyalitas konsumen terhadap Lab Bisnis. Pernyataan-pernyataan tersebut antara lain:

1. Saya akan melanjutkan berbelanja produk di Lab Bisnis AN Politeknik Negeri Bandung. (Q1)

2. Pelayanan Lab Bisnis AN sudah baik sehingga saya akan tetap berbelanja produk yang sama dan juga berbeda di Lab Bisnis AN Politeknik Negeri Bandung. (Q2)

3. Saya tidak tertarik dengan tempat berbelanja lain selain Lab Bisnis AN POLBAN. (Q3) 
4. Produk yang ditawarkan Lab Bisnis AN berkualitas, sehingga saya akan selalu berbelanja disana. (Q4)

5. Saya merekomendasikan produk Lab Bisnis AN Polban kepada orang lain. (Q5)

6. Saya tidak pernah menyebarkan isu negatif tentang Lab Bisnis Polban. (Q6)

Selanjutnya variabel-variabel tersebut dianalisis lebih lanjut untuk mengetahui tingkat korelasi antar variabelnya apakah sudah memenuhi standar atau tidak. Tingkat korelasi ini dapat menggunakan uji statistik Kaiser-Meyer-Olkin (KMO) dan uji Bartlett's. Uji KMO bertujuan untuk memastikan apakah data yang akan dianalisis dianggap cukup, sehingga dapat dilakukan análisis faktor. Sedangkan uji Bartlett's bertujuan untuk memastikan apakah ada korelasi yang signifikan antar variable yang diteliti.

Tabel 2 . Hasil Uji KMO dan Bartlett's

\begin{tabular}{|c|c|c|}
\hline \multicolumn{2}{|c|}{ Kaiser-Meyer-Olkin Measure of Sampling Adequacy. } & .781 \\
\hline \multirow{3}{*}{ Bartlett's Test of Sphericity } & Approx. Chi-Square & 310.010 \\
\hline & df & 15 \\
\hline & Sig. & .000 \\
\hline
\end{tabular}

Seperti yang ditunjukkan oleh Tabel 2 , diketahui bahwa nilai uji Kaiser-Meyer-Olkin (KMO) adalah 0.781, dimana menurut Santoso (2006), jika nilai KMO adalah sebesar .7, maka dapat dikatakan sampel dalam penelitian dikategorikan menengah dan cukup untuk dilakukan análisis faktor. Sedangkan nilai dari uji Bartlett's bernilai .000 yang berarti terdapat korelasi yang sangat signifikan antar variable.

Selanjutnya perlu diketahui tentang nilai Measure of Sampling Adequacy (MSA) yang dapat dilihat dari tabel matriks anti-image. Tabel 3 menunjukkan bahwa nilai dari setiap variabel yang diukur dalam penelitian adalah lebih dari 0.5 , yang berarti variabel-variable dalam penelitian masih dapat diprediksi dan dianalisis lebih lanjut.

\begin{tabular}{|c|c|c|}
\hline Variabel & MSA & $\mathrm{MSA}^{\mathrm{a}}$ \\
\hline Q1 & .745 & .747 \\
\hline Q2 & .757 & .756 \\
\hline Q3 & .812 & .808 \\
\hline Q4 & .781 & .777 \\
\hline Q5 & .827 & .826 \\
\hline Q6 & .814 & .783 \\
\hline
\end{tabular}

Setelah dilakukan Uji KMO dan Bartlett's serta mendapatkan nilai MSA yang menunjukkan bahwa variabel memenuhi persyaratan untuk dilakukan análisis, langkah selanjutnya adalah menentukan atau mengekstraksi semua variabel yang telah lulus uji sehingga terbentuk satu atau lebih faktor. Metode análisis faktor yang digunakan dalam penelitian ini adalah Principle Component Analysis dan rotasi faktor dengan metode varimax.

Selanjutnya, dilakukan pengelompokkan variabel-variabel yang akan dimasukkan ke dalam masing-masing faktor. Cara mengelompokkan variabel tersebut dapat dilakukan 
dengan cara melihat Tabel 5 yaitu Rotated Component Matriks. Penentuan pemasukan sebuah variabel ke dalam sebuah faktor tertentu dilihat dari nilai terbesar korelasi antara variabel dengan faktor.

Tabel 4 . Rotated Component Matrix

\begin{tabular}{|l|r|r|r|r|}
\hline \multirow{2}{*}{} & \multicolumn{3}{|c|}{ Component } & \multicolumn{2}{c|}{ Component $^{\mathrm{a}}$} \\
\cline { 2 - 6 } & 1 & 2 & 1 & \multicolumn{1}{c|}{2} \\
\hline Q2 & $\mathbf{. 8 5 4}$ & .111 & $\mathbf{. 8 4 7}$ & .081 \\
Q1 & $\mathbf{. 8 2 2}$ & -.102 & $\mathbf{. 7 9 8}$ & -.119 \\
Q4 &. $\mathbf{7 5 9}$ & .378 &. $\mathbf{7 8 2}$ & .328 \\
Q5 & $\mathbf{. 7 4 6}$ & .276 & $\mathbf{. 7 7 0}$ & .202 \\
Q6 & -.047 & $\mathbf{. 8 3 7}$ & -.042 & $\mathbf{. 8 7 8}$ \\
Q3 & .367 & $\mathbf{. 6 0 7}$ & .435 & $\mathbf{. 5 0 3}$ \\
\hline
\end{tabular}

Dari penjelasan diatas maka dapat disimpulkan bahwa Faktor 1 terdiri dari variabel Q2, Q1, Q4, dan Q5. Dengan Faktor 2 terdiri dari variabel Q6 dan Q3. Faktor 1 terdiri dari unsur pengulangan pembelian dan referrals, dimana pengulangan pembelian dinyatakan dengan sikap responden yang akan tetap berbelanja produk yang sama dan juga berbeda dan akan melanjutkan berbelanja di Lab Bisnis untuk kedepannya. Faktor 1 juga mengandung unsur referral yang berarti responden sebagai pelanggan Lab Bisnis merekomendasikan mengenai produk Lab Bisnis kepada orang lain. Untuk Faktor 1, peneliti mengkonfirmasi tentang karakteristik dari loyalitas yaitu repeat buying dan referrals. Sedangkan pada Faktor 2, peneliti mengkonfirmasi bahwa terdapat unsur retention sebagai salah satu karakteristik loyalitas konsumen. Hal tersebut dicirikan dengan sikap responden sebagai pelanggan yang menjelaskan tentang ketertarikannya dengan tempat berbelanja lain selain Lab Bisnis dan sikap tidak pernah menyebarkan isu negatif tentang Lab Bisnis. Penjelasan tersebut peneliti rangkum dalam Tabel 6 berikut.

Tabel 5 . Summary Pengelompokan Faktor Loyalitas Konsumen Lab Bisnis

\begin{tabular}{|c|c|c|}
\hline Faktor & Pernyataan & $\begin{array}{l}\text { Faktor } \\
\text { Loading }\end{array}$ \\
\hline $\begin{array}{l}\text { Faktor } 1 \\
\text { Repeat buying } \\
\text { dan Referrals }\end{array}$ & $\begin{array}{l}\text { 1. Pelayanan Lab Bisnis AN sudah baik sehingga saya akan tetap } \\
\text { berbelanja produk yang sama dan juga berbeda di Lab Bisnis } \\
\text { AN Politeknik Negeri Bandung. (Q2) } \\
\text { 2. Saya akan melanjutkan berbelanja produk di Lab Bisnis AN } \\
\text { Politeknik Negeri Bandung. (Q1) } \\
\text { 3. Produk yang ditawarkan Lab Bisnis AN berkualitas, sehingga } \\
\text { saya akan selalu berbelanja disana. (Q4) } \\
\text { 4. Saya merekomendasikan produk Lab Bisnis AN Polban kepada } \\
\text { orang lain. (Q5) }\end{array}$ & $\begin{array}{r}.798 \\
.782\end{array}$ \\
\hline Faktor 2 & $\begin{array}{l}\text { 1. Saya tidak tertarik dengan tempat berbelanja lain selain Lab } \\
\text { Bisnis AN POLBAN. (Q3) }\end{array}$ & .878 \\
\hline
\end{tabular}




\section{KESIMPULAN DAN SARAN}

\section{Kesimpulan}

Dari berbagai penjelasan hasil penelitian diatas, maka penelitian ini menyimpulkan bahwa, sesuai dengan karakteristik loyalitas konsumen yang disampaikan oleh Griffin (2002), berdasarkan analisis faktor dalam penelitian terdapat dua factor loyalitas konsumen yang terlihat pada konsumen Lab Bisnis, yaitu factor repeat buying dan referrals \& retention. Repeat buying \& Referrals ditandai dengan adanya pernyataan konsumen yang menyatakan bahwa konsumen akan melanjutkan berbelanja produk di Lab Bisnis, sedangkan referrals dicirikan dengan sikap konsumen yang merekomendasikan produk Lab Bisnis kepada orang lain. Untuk retention, factor ini ditandai dengan kaitannya ketertarikan konsumen kepada tempat berbelanja lain selain Lab Bisnis dan juga penyebaran isu negative mengenai Lab Bisnis.

Berkaitan dengan tingkat loyalitas konsumen Lab Bisnis berbasis ritel swalayan, berdasarkan hasil analisis deskriptif, tingkat loyalitas konsumen dalam factor repeat buying dan referrals cukup tinggi. Hal tersebut dilihat dari $47 \%$ konsumen setuju dan $25 \%$ konsumen sangat setuju bila harus melanjutkan berbelanja produk di Lab Bisnis. Lebih lanjut, berkaitan dengan pelayanan Lab Bisnis yang baik membuat 38\% konsumen setuju dan 21\% konsumen sangat setuju untuk tetap berbelanja produk yang sama dan berbeda di Lab Bisnis. Akan tetapi, bila dihubungkan dengan kualitas produk, hanya sekitar 29\% konsumen yang setuju dan 7\% konsumen yang sangat setuju untuk selalu berbelanja di Lab Bisnis. Hal ini perlu menjadi perhatian untuk perbaikan pengembangan Lab Bisnis kedepan. Dalam hal referral, 43\% konsumen setuju dan $11 \%$ konsumen sangat setuju untuk merekomendasikan produk Lab Bisnis kepada orang lain. Hal ini menunjukkan bahwa pada dasarnya Lab Bisnis mempunyai produk yang bisa memenuhi kebutuhan konsumen, akan tetapi dengan kualitas yang belum cukup baik, sehingga perlu adanya peningkatan kualitas produk dari Lab Bisnis.

Kemudian, berkaitan dengan factor retention, tingkat retention konsumen Lab Bisnis dapat dikatakan rendah. Hal ini dapat dilihat dari adanya $33 \%$ konsumen yang tidak setuju dan $12 \%$ konsumen yang sangat tidak setuju dengan ketidaktertarikan berbelanja di tempat lain. Secara sederhana, dapat dikatakan bahwa Lab Bisnis bukanlah pilihan utama dari konsumen. Namun, kondisi yang baik terjadi ketika 40\% konsumen setuju dan 32\% konsumen sangat setuju untuk tidak pernah menyebarkan isu negative tentang Lab Bisnis. Hal tersebut dapat dijadikan sebagai indicator bahwa pengembangan Lab Bisnis dapat ditingkatkan, dapat menggunakan strategi pemasaran word of mouth yang maksimal.

\section{Saran}

Berdasarkan kesimpulan diatas, maka peneliti mempunyai beberapa saran yang dapat diaplikasikan untuk meningkatkan loyalitas konsumen Lab Bisnis. Lab Bisnis perlu menerapkan rencana untuk meningkatkan loyalitas konsumen tidak hanya untuk mendatangkan konsumen yang selalu datang kembali untuk berbelanja, namun juga menambah nilai untuk konsumen dengan beberapa cara berikut yang diambil dari berbagai sumber.

Andafcorp.com mengulas bahwa untuk meningkatkan loyalitas konsumen, perusahaan perlu memenuhi dan melebihi ekspektasi dari para konsumennya. Perusahaan harus mampu memberikan lebih dari kebutuhan dasar konsumen sehingga konsumen merasakan kepuasan sehingga menjadikan konsumen loyal. Perusahaan juga perlu mempertahankan dan meningkatkan kualitas produk yang dihasilkan secara terus menerus. Selanjutnya, perusahaan juga perlu membangun kedekatan emosional kepada konsumen. Keterikatan emosional ini dapat dibangun dengan kualitas layanan yang prima dan mengerti apa yang konsumen 
butuhkan. Dalam hal ini SDM berperan sangat penting untuk membangun kedekatan emosional dengan konsumen. Hal terakhir yand dapat dilakukan oleh Lab Bisnis untuk meningkatkan loyalitas konsumen adalah dengan membuat berbagai macam program loyalitas. Seperti misalnya, program membership yang memfasilitasi setiap member untuk bisa mendapatkan keuntungan-keuntungan dalam berbelanja seperti diskon untuk pembelian selanjutnya. Namun, program loyalitas seperti ini perlu dikaji lebih mendalam dan dipastikan bahwa program loyalitas yang dibangun memang dibutuhkan oleh konsumen, sehingga konsumen merasa senang bukan sebaliknya membuat konsumen merasa kesal.

\section{DAFTAR PUSTAKA}

Auh, S., \& Johnson, M. (2005). Compatibility effects in evaluations of satisfaction and loyalty. Journal of Economic Psychology, Vol. 26, 35-57.

Baloglu, S. (2002). Dimensions of customer loyalty: separating friends from well wishers. Cornell Hotel and Restaurant Administration Quartely, Vol. 43, 47-59.

Day, G. (1969). A two-dimensional concept of brand loyalty. Journal of Advertising Research, Vol. 9, 29-35.

Dick, A., \& Basu, K. (1994). Customer Loyalty: Toward an Integrated Conceptual Framework. Journal of the Academy of Marketing Science, Vol. 22, 99-113.

Griffin, J. (2002). Customer Loyalty - How to Earn It, How to Keep It. Singapore: Lexington Bodes.

Kumar, V., \& Shah, D. (2006). Building and sustaining profitable customer loyalty for the 21st century. Journal of Retailing, Vol. 80, 317-329.

Oliver, R. (1997). Satisfaction A Behavioral Perspective on The Consumer. New York: Printce Hill.

Santoso, S. (2006). Seri Solusi Bisnis Berbasis TI: Menggunakan SPSS untuk Statistik Multivariat. Jakarta: Elex Media Komputindo.

Simamora, B. (2005). Analisis Multivariat Pemasaran. Jakarta: PT.Gramedia Pustaka Utama. Sugiama, A. G. (2008). Metode Riset Bisnis dan Manajemen. Bandung: Guardaya Intimarta. 